\title{
Recent advances in understanding and improving photosynthesis
}

\author{
Alicia V. Perera-Castro ${ }^{1}$ Jaume Flexas \\ ${ }^{1}$ Department of Biology, Universitat de les Illes Balears, INAGEA, Palma de Mallorca, Spain
}

\begin{abstract}
Since 1893, when the word "photosynthesis" was first coined by Charles Reid Barnes and Conway MacMillan, our understanding of the elements and regulation of this complex process is far from being entirely understood. We aim to review the most relevant advances in photosynthesis research from the last few years and to provide a perspective on the forthcoming research in this field. Recent discoveries related to light sensing, harvesting, and dissipation; kinetics of $\mathrm{CO}_{2}$ fixation; components and regulators of $\mathrm{CO}_{2}$ diffusion through stomata and mesophyll; and genetic engineering for improving photosynthetic and production capacities of crops are addressed.
\end{abstract}

\section{Keywords}

light harvesting, photosystem, rubisco, stomatal conductance, mesophyll conductance, engineering photosynthesis

\section{Peer Review}

The peer reviewers who approve this article are:

1. Asaph B. Cousins, School of Biological Sciences, Washington State University, WA, USA

Competing interests: No competing interests were disclosed.

2. Esa Tyystjärvi, Department of Biochemistry/Molecular Plant Biology, University of Turku, Turku, Finland Competing interests: No competing interests were disclosed. 
*Corresponding author: Jaume Flexas (jaume.flexas@uib.es)

Competing interests: The authors declare that they have no competing interests.

Grant information: Alicia V. Perera-Castro and Jaume Flexas's research was supported by the project EREMITA (PGC-2018-093824-B-C41) from the Ministerio de Economía y Competitividad (MINECO, Spain) and the ERDF (FEDER). The Ministerio de Educación, Cultura y Deporte (MECD, Spain) supported a pre-doctoral fellowship (FPU-02054) awarded to Alicia V. Perera-Castro.

The funders had no role in study design, data collection and analysis, decision to publish, or preparation of the manuscript.

Copyright: (C) 2020 Flexas J et al. This is an open access article distributed under the terms of the Creative Commons Attribution License, which permits unrestricted use, distribution, and reproduction in any medium, provided the original work is properly cited.

How to cite this article: Perera-Castro AV and Flexas J. Recent advances in understanding and improving photosynthesis. Faculty Reviews 2020 9:(5) https://doi.org/10.12703/E]9-5

Published: 06 Nov 2020, Faculty Reviews 9:(5) https://doi.org/10.12703/E]9-5 


\section{Introduction}

Photosynthesis is the chemical reaction that sustains most life on Earth. Since the description of the Hill reaction and the Calvin-Benson cycle ${ }^{1-3}$, knowledge about their components, regulation, and limitations experienced a vertiginous increase. It is widely known that plants have important handicaps related to photosynthesis. First, the photosynthetic apparatus that harvests and transforms light energy into electron transport for the generation of ATP and $\mathrm{NADPH}_{2}$ must cope with the generation of dangerous reactive oxygen species (ROS) ${ }^{4}$ and most of the energy must be "wasted" in dynamic heat dissipation mechanisms ${ }^{5}$. Second, the enzyme that catalyzes $\mathrm{CO}_{2}$ fixation in the Calvin-Benson cycle-ribulose 1,5-bisphosphate carboxylase oxidase or rubisco-is inefficient owing to several intrinsic characteristics, the most notable being the competitiveness between carboxylation and oxidation processes, since the oxidation of D-ribulose-1,5-bisphosphate results in the energetically expensive but perhaps convenient photorespiratory pathway ${ }^{6}$. And, third, the diffusion of $\mathrm{CO}_{2}$ from the atmosphere surrounding leaves through stomata and the leaf tissues to the carboxylation sites in the chloroplast stroma, where rubisco is located, is a dynamic pathway that is full of barriers and includes gaseous, lepidic, and aqueous phases, the latter with a small solubility and diffusivity for $\mathrm{CO}_{2}$.

In the last few years, researchers have tried to determine the limitations and components of the processes described above. Engineering photosynthesis targeting different aspects of photosynthesis and its regulation has also advanced. The aim of this review is to compile and organize these advances in photosynthesis from the last few years and suggest a next horizon for plant physiologists, ecologists, and geneticists.

\section{Light harvesting and use}

Light energy is absorbed and transferred to the photosystem II (PSII) core by the light-harvesting complex II (LHCII). The way this absorption is regulated is relevant, since excessive and/or unbalanced exposure to light can lead to the generation of ROS and, in the long term, to the initiation of senescence processes ${ }^{7}$. Some isoforms of LHCII upregulate its transcription and translation as a response to high irradiance ${ }^{8,9}$, and their interaction with PsbS-a protein that plays a special role in photoprotection-has been described in detail ${ }^{10}$. Furthermore, Janil et $a l .{ }^{11}$ discussed the enhanced dimerization of LHCII under strong light conditions as a photoprotective response partially responsible for the dissipation of excess excitation. In line with this, Albanese et al. ${ }^{12}$ recently described how the organization of PSII-LHCII supercomplexes changed with the diversification of land plants, contributing to their adaptability to different light environments. However, photoprotective processes and their ecophysiological implications remain far from fully characterized ${ }^{5}$. At the extreme opposite to excess light, shaded leaves within the canopy exhibit lower photosynthesis rates and slower activation of rubisco, stomata opening, and relaxation of photoprotection states. These delays, especially in rubisco activation, have been estimated to decrease wheat assimilation by $21 \%$ in shade to sun transitions ${ }^{13}$. Indeed, the fact that light is often in excess in the most illuminated leaves while limited in the shaded leaves within the canopy has led to the suggestion that lowering chlorophyll content may result not only in negligible effects on leaf-level photosynthesis rates but also in a higher distribution of light harvesting through the canopy, hence potentially enhancing whole plant photosynthesis rates and yield ${ }^{14,15}$. On the other hand, alterations of the canopy structure have also been suggested as a mechanism to improve light interception and canopy assimilation (see the recent review by Morales et al. ${ }^{16}$ and references therein), mainly through long-term breeding but also through hormonal and/or genetic means ${ }^{17}$.

Besides studies on the photosynthetic management of light amount, the effect of light quality on photosynthesis-related issues has also been addressed. It is widely known that growing under blue light conditions induces lower photosynthetic rates, increases the synthesis of carotenoids and anthocyanins and the photoprotection capacity, and decreases stomata size while increasing their density ${ }^{18}$. Light quality also affects the level of ROS and the expression of antioxidant enzymes ${ }^{19}$. Recently, Górecka et al. ${ }^{20}$ demonstrated that PsbS is not only a compulsory protein for enhancing dissipation of the excess of light energy as heat but also relevant for the red/blue lightassociated enhancement of tolerance to UV-C and chloroplast signaling for light memory. A recent study has also described a species-specific response of photosynthesis to the quality of light independent of its intensity ${ }^{21}$. These interspecific differences in light response represent an opportunity to deeply understand the elements of light harvesting and their adaptation to different light environments.

Rubisco kinetics and $\mathrm{CO}_{2}$-concentrating mechanisms Interspecific variation of rubisco kinetics has also been a focus over the last several years. In two almost simultaneously published works, Hermida-Carrera et al..$^{22}$ and Orr et al..$^{23}$ assessed rubisco kinetics, their temperature dependency, and the aminoacidic replacements in the large subunit of rubisco in many crop species. Orr et al. ${ }^{23}$ extended their study to include 75 angiosperm species and found that some undomesticated plants presented inherently better rubisco kinetics, being thus a potential source for crop photosynthesis improvement. Iñiguez et $a l .{ }^{24}$ and Flamholz et al..$^{25}$ extended the analysis of differences in rubisco catalysis across the phylogeny and correlated them with the incidence of $\mathrm{CO}_{2}$ concentration mechanisms (CCMs), showing that organisms that had evolved CCMs tended to have faster rubiscos yet with lower affinity and specificity for $\mathrm{CO}_{2}$. Hermida-Carrera et $a l .^{26}$ found similar results when comparing rubisco catalytic traits of orchids and bromeliads with and without CCMs. These results suggest that equipping $\mathrm{C}_{3}$ crops with CCMs could be another strategy for fueling their photosynthetic capacity.

$\mathrm{C}_{4}$ photosynthesis is often envisaged as an efficient CCM and thus converting typical $\mathrm{C}_{3}$ crops into $\mathrm{C}_{4}$ has been a long-standing goal, resulting in the development of large-scale projects like the ongoing C4Rice (https://c4rice.com/), yet the goal has not been fully accomplished $\operatorname{yet}^{27}$. Furthermore, transitioning from mostly $\mathrm{C}_{3}$ to mostly $\mathrm{C}_{4}$ crops may be an 
efficient way to enhance productivity in a world exhibiting increased global aridity ${ }^{28,29}$, as it has been shown that in some cases $\mathrm{C}_{4}$ plants performed better under drought than did $\mathrm{C}_{3}$ species $^{30}$. In the same vein, introducing crassulacean acid metabolism (CAM) into $\mathrm{C}_{3}$ crops has been suggested as a strategy to increase water use efficiency, i.e. to maximize $\mathrm{CO}_{2}$ fixation with minimum water loss through transpiration ${ }^{31,32}$. On the other hand, other CCMs like those found in algae and other aquatic organisms (e.g. pyrenoids and carboxysomes) have been reported to concentrate more $\mathrm{CO}_{2}$ around rubisco than $\mathrm{C}_{4}$ photosynthesis. Hence, while the $\mathrm{C}_{4}$ mechanism allows $\mathrm{CO}_{2}$ concentrations around rubisco of at least 10-times higher than those of the surrounding atmosphere ${ }^{33}$, eukaryotic algae like Chlamydomonas containing pyrenoids can concentrate $\mathrm{CO}_{2} \quad 40-$ times $^{34}$ and prokaryotic cyanobacteria possessing carboxysomes 100-times ${ }^{35}$ higher than the surrounding atmosphere. Consequently, the potential expression of cyanobacterial and algal CCMs in crop plants has been proposed as an opportunity to improve their photosynthesis $^{36}$.

Despite the inefficiencies of light harvesting and rubisco, photochemical and/or biochemical limitations to photosynthesis are not larger than the diffusional limitations related to both stomatal and mesophyll resistances to $\mathrm{CO}_{2}$ in most of the studied species $^{37-45}$. Gago et al. ${ }^{46}$ recently presented a compilation of photosynthetic limitations across land plants' phylogenies, in which angiosperms showed a well-balanced distribution among biochemical, stomatal, and mesophyll limitations; photosynthesis in gymnosperms and ferns was co-limited mostly by stomatal and mesophyll limitations; and in bryophytes and lycophytes the mesophyll limitation largely predominated.

\section{Mesophyll conductance components}

Mesophyll conductance to $\mathrm{CO}_{2}\left(g_{\mathrm{m}}\right)$ depends on several leaf structures that comprise the pathway from sub-stomatal cavities to carboxylation sites of rubisco. Intercellular air spaces, cell walls, plasma membranes, cytosol, double chloroplast membranes, and stroma offer resistance to $\mathrm{CO}_{2}$ diffusion. Values of $g_{\mathrm{m}}$ vary strongly among species, and short-term changes in $g_{\mathrm{m}}$ have been reported in response to many different environmental variables ${ }^{46-49}$, although a part of them could reflect methodological errors or uncertainties ${ }^{50-52}$. While interspecific differences are largely explained by anatomical traits $\mathrm{s}^{37-39,53,54}$, short-term changes cannot be explained either by variable leaf anatomy or by the temperature coefficient reported for $\mathrm{CO}_{2}$ diffusion ${ }^{55-57}$. Consequently, it has been suggested that a biochemically facilitated $\mathrm{CO}_{2}$ diffusion must contribute to $g_{\mathrm{m}}$ instead of solely physical diffusion ${ }^{56,58-60}$. Short-term chloroplast movement, aquaporins, and carbonic anhydrases have been indicated as candidates ${ }^{53,56,61}$, although their actual involvement is far away from being conclusive.

For instance, despite the fact that chloroplast surface area facing intercellular airspaces per unit leaf area $\left(S_{\mathrm{c}} / S\right)$ is one of the anatomical parameters more correlated with $g_{\mathrm{m}}{ }^{37,53,54}$, no evidence for an association between short-term changes of $g_{\mathrm{m}}$ and chloroplast movement or leaf anatomy has been found ${ }^{57,62,63}$, with the exception of Arabidopsis mutants with phytochromemediated impairment of the chloroplast avoidance response ${ }^{64}$. In a similar way, the contribution of carbonic anhydrases to $g_{\mathrm{m}}$ variations remains elusive and is a matter of ongoing debate ${ }^{65}$. The most recent studies showed that latitudinal variation of $g_{\mathrm{m}}$ correlates with variations in carbonic anhydrase activity ${ }^{66,67}$ and that a coupled inhibition of both $g_{\mathrm{m}}$ and carbonic anhydrases is obtained with treatment with mercuric chloride ${ }^{68}$. Han et al. ${ }^{69}$ also reported a decrease in the expression of carbonic anhydrase (CA1) during drought. On the contrary, Kolbe and Cousins ${ }^{70}$ did not find any variation in $g_{\mathrm{m}}$ in five lines of maize despite their differences in carbonic anhydrase activity.

The role of aquaporins as enhancers of $\mathrm{CO}_{2}$ diffusion across membranes has been widely reported ${ }^{48,71}$. Changes in $g_{\mathrm{m}}$ had been induced by inhibitors of aquaporins ${ }^{68,72}$ in transgenics ${ }^{73-76}$ and in mutants ${ }^{77-80}$. Direct measurement of the $\mathrm{CO}_{2}$ permeability of chloroplasts also revealed a $50 \%$ reduction in chloroplasts of an Arabidopsis aquaporin mutant as compared to the wild-type ${ }^{81}$. Despite these findings, Kromdijk et al. ${ }^{82}$ recently reported null differences in $g_{\mathrm{m}}$ among several knockout aquaporin mutants and wild-type, probably due to functional redundancy of aquaporin isoforms.

Additionally, the relative importance of these biochemical processes and anatomical traits in regulating $g_{\mathrm{m}}$ remains unknown. Furthermore, recent studies showed uncertainty about estimating some relevant anatomical parameters from microscopic images of 2D cross-sections compared to 3D microscopy, especially the mesophyll surface area exposed to air-filled spaces $^{83}$ and chloroplast volume ${ }^{84}$. This could partially explain the differences in the $g_{\mathrm{m}}$ calculated from chlorophyll fluorescence and/or gas exchange and $g_{\mathrm{m}}$ calculated so far from anatomical models ${ }^{38,39,53,85,86}$. Earles et al. $^{87}$ have emphasized the need to improve 3D techniques and models to properly characterize leaf-level photosynthesis in its whole complexity.

Within the anatomical components, $S_{c} / S$ and cell wall thickness $\left(T_{\mathrm{cw}}\right)$ have been recognized as especially determinant for $g_{\mathrm{m}}{ }^{46}$. Besides the effect of $T_{\mathrm{cw}}$, an effect of cell wall composition and porosity in short- and long-term variations of $g_{\mathrm{m}}$ has been suggested ${ }^{88,89}$, and recently the first empirical evidence was provided. Thus, a reduction of $g_{\mathrm{m}}$ was observed by Ellsworth et $a l . .^{90}$ in mutants with disrupted $\beta$-glucosyl polysaccharides of the cell wall. More recent studies have shown that the decrease of $g_{\mathrm{m}}$ provoked by drought, salinity, and low temperatures is coupled with variations in the relative levels of cellulose, hemicelluloses, and pectins ${ }^{91,92}$. More evidence is needed to understand how cell wall composition affects porosity and $\mathrm{CO}_{2}$ diffusion.

\section{Stomatal conductance}

As mentioned above, an additional important limiting factor of photosynthesis is the stomatal conductance $\left(g_{\mathrm{s}}\right)$. Several internal and environmental factors are widely known to affect $g_{\mathrm{s}}$. Stomatal shape, size, density, and clustering influence $g_{\mathrm{s}}$ 
and therefore photosynthesis ${ }^{93}$. These traits are established during leaf development and regulated by several phytohormones, especially abscisic acid (ABA) ${ }^{94}$. Light, $\mathrm{CO}_{2}$, and water supply also affect $g_{\mathrm{s}}^{95,96}$.

The speed of $g_{\mathrm{s}}$ responses to light and $\mathrm{CO}_{2}$ has been recently compared among phylogenetic plant groups. Although fern and lycophyte stomata are not insensitive to light and $\mathrm{CO}_{2}$, their response is lower and slower than that observed in angiosperms $^{97-100}$. Furthermore, unlike angiosperms, fern and lycophyte stomata do not respond to endogenous levels of $\mathrm{ABA}^{97,98}$ and their closure is based on a passive response of guard cells to dehydration ${ }^{101}$. The mechanism that explains this different response remains unclear, although it is likely related to differences in the molecular mechanisms operating in the guard cells along the phylogeny. Among other factors affecting $g_{\mathrm{s}}$ (kinases, anion channels, etc.), it is known that carbonic anhydrases can be involved in the biochemical mechanism by which guard cells of angiosperms sense $\mathrm{CO}_{2}$ (see the review by Engineer et al. ${ }^{95}$ ), although details of signal transduction and the identity of the second messengers (bicarbonate, protons) are still debated. Furthermore, a higher $\mathrm{CO}_{2}$ assimilation related to phosphoenolpyruvate carboxylase activity followed by gluconeogenesis and maybe sucrose synthesis has been described for guard cells in comparison to those of mesophyll cells of $\mathrm{C}_{3}$ plants ${ }^{102}$.

In addition, recent studies suggest that stomata movement is regulated by mesophyll-derived signals. Sucrose has been identified as an important metabolite for the regulation of stomatal opening and closure ${ }^{100,103,104}$. Wang et al. ${ }^{105}$ reported that the maize mutant cst 1 - with an impaired membrane glucose transporter CST1 located in the subsidiary cell membrane-presented lower $g_{\mathrm{s}}$, lower photosynthesis, and earlier senescence than the wild-type. In line with this, Fujita et al. ${ }^{106}$ demonstrated that stomatal responses are disrupted when a membrane excluding molecules of 100-500 Da is transplanted between mesophyll and guard cells, which would avoid the transport of sucrose, malate, and ABA. In a study of ABA-regulated genes in Arabidopsis, Yoshida et al. ${ }^{107}$ found highly expressed genes in guard cells related to the tricarboxylic acid cycle and sucrose and hexose transport and metabolism. These studies support the hypothesis of stomatal regulation driven by carbohydrate/hormone-related mesophyll signals. However, the differences in the mechanism of mesophyll cell signaling and in guard cell metabolism among fern, lycophytes, and angiosperms-both anisohydric and isohydric species-remain unknown.

Even in angiosperms, the predominance of hormonal $v s$. hydraulic stomatal regulation is currently under debate ${ }^{108-110}$. Traditionally, stomatal closure has been understood as a safety valve to prevent cavitation (see Hochberg et al. ${ }^{111}$ and references therein). However, a detailed chronological description of the drought response of $g_{\mathrm{s}}$ and hydraulic conductance $\left(K_{\text {leaf }}\right)$ in rice revealed that the decline in $K_{\text {leaf }}$ preceded and probably triggered the decline of $g_{\mathrm{s}}$ and $g_{\mathrm{m}}{ }^{108}$. Nadal et al. ${ }^{112}$ suggested that both types of drought response are not necessarily incompatible and can be related to the spectrum of the iso-anisohydric response of angiosperms.

\section{Engineering photosynthesis}

While there are some opposing views ${ }^{113}$, improving photosynthesis is often envisaged as an important goal for improving crop yields ${ }^{114-117}$, including the cultivation of photosynthetic microorganisms, which constitutes a huge and important branch of bioengineering for bioenergy production ${ }^{118,119}$. Regarding land plant bioengineering, optimizing production with a minimum investment of resources (water, land, and nutrients) is the aim of ongoing large-scale projects, such as the already mentioned C4rice or the RIPE project (https://ripe.illinois.edu/). Several targets for manipulation-including all those mentioned in the above sections-have been proposed with the aim of improving photosynthesis and crop yield ${ }^{120,121}$. Neglecting which are the main limitations for photosynthesis when targeting genes for improving photosynthesis is an example of the mutual disregard that ecophysiologists and biotechnologists have had for each other in the last few decades ${ }^{122}$, i.e. biotechnologists attempting to improve photosynthetic targets that ecophysiologists were showing to be non-limiting for photosynthesis. Using a model approach, Flexas ${ }^{116}$ showed that only modest improvements of photosynthesis can be expected from relaxing only one limiting factor, since photosynthetic limitations are generally well-balanced in angiosperms ${ }^{46}$. Nevertheless, even with this relatively modest approach, increases of yield of $>40 \%$ have been reported in some successful attempts ${ }^{117}$.

Rubisco kinetics have been among the most common targets for improving photosynthesis. All the advances in rubisco engineering have implied important improvements in our understanding of rubisco regulation and assembly but unsuccessfully improved the catalytic performance of rubisco ${ }^{123,124}$ or photosynthesis ${ }^{125}$. While faster rubisco from cyanobacteria have been successfully engineered in transplastomic tobacco ${ }^{126}$, post-transcriptional assembly of functional rubisco in large enough quantities remains a limiting factor, likely due to the inability of local chaperones to deal with foreign rubisco fragments (see Whitney et al. ${ }^{127}$ and their attempt to solve this problem by the use of ancillary chaperone genes). For this reason, this is a very active area of ongoing research ${ }^{127,128}$. Rubisco activase is another potential limiting factor, as Fukuyama et al. ${ }^{129}$ also showed how increased expression of rubisco activase resulted in a negative correlation with rubisco content.

Besides achieving more efficient rubiscos, an alternative strategy has been to increase $\mathrm{CO}_{2}$ concentration by either introducing elements of algal CCMs or bypassing photorespiration by different processes. While theoretically CCMs should increase photosynthesis ${ }^{130}$, introducing $\mathrm{CCMs}$ into either tobacco ${ }^{131}$ or Arabidopsis failed to increase photosynthesis ${ }^{132,133}$, probably because of insufficient encapsulation of local rubisco in the foreign carboxysomes, which can be improved by simultaneously replacing the native large subunit of rubisco ${ }^{134}$. Additional elements might also be essential for a proper assemblage of 
fully functional carboxysome-rubisco CCMs, as recently demonstrated for bestrophin-like proteins ${ }^{135}$.

More successful results have been obtained when the photorespiration pathway has been manipulated in Arabidopsis and tobacco ${ }^{136,137}$. While photosynthesis increases ${ }^{136}$, biomass production has been shown to vary from decreasing through unaffected to increasing by $10-50 \%{ }^{117,138}$. Recently, South et al. ${ }^{137}$ obtained a $24 \%$ maximum increase of biomass when glycolate byproducts of photorespiration are processed by foreign malate synthase and a green algal glycolate dehydrogenase, substituting the native pathway. Tissue-specific overexpression of one of the subunits forming in the glycine dehydrogenase system also increased biomass yield by $13-38 \%$ in tobacco ${ }^{139}$. This is a very promising approach for improving grain crop yields in the near future.

Also, modifications of the Calvin-Benson cycle have resulted in improved photosynthesis and yield. Overexpression or transgenic insertion of several enzymes involved in the cycle (mostly sucrose bis-phosphatase-SBPase-and fructose bis-phosphatase-FBPase-but also FBPaldolase) has also resulted in increased photosynthesis and dry weights, although generally not in improved yield. However, Driever et al. ${ }^{140}$ showed an up to $40 \%$ increase in grain yield in wheat, and Simkin et al. ${ }^{141}$ a $35-53 \%$ increase in seed yield in Arabidopsis. Furthermore, overexpression of FBP/SBPase has been recently combined with an improved electron transport by the addition of the algae cytochrome $\mathrm{C}_{6}$, which also resulted in up to $53 \%$ of increase of biomass ${ }^{142}$. These results open up the possibility of using this approach for improving crop yields in the very near future.

Few attempts have focused on modifying $\mathrm{CO}_{2}$ diffusive characteristics of leaves. Altered stomatal density in epidermal patterning factor (EPF) mutants of Arabidopsis ${ }^{143}$ and wheat ${ }^{144}$ resulted in an increased photosynthetic water-use efficiency (WUE) but not increased photosynthesis itself. Similarly, Yang et al. ${ }^{145}$ showed that overexpression of the ABA receptors RCAR6/PYL12 increases the sensitivity of the stomata in Arabidopsis lines, reducing $\mathrm{g}_{\mathrm{s}}$ even in the absence of water stress without affecting photosynthesis, thus also enhancing WUE. As described in previous sections, $g_{s}$ was also enhanced by overexpression of glucose transporters in subsidiary cell membranes ${ }^{105}$.

Generally speaking, increasing stomatal conductance does not result in enhanced photosynthesis because stomatal limitations are generally minor in the absence of stress. However, during leaf development, the presence of well-developed and functional stomata appears to be the main driver of the development of mesophyll porosity, which is an essential anatomical trade favoring $g_{\mathrm{m}}$ and hence photosynthesis ${ }^{146}$. This finding is remarkable as it implies that, while it is likely that a mesophyll signal is involved in stomata regulation (see above sections), stomata define the developmental set-up of the mesophyll structure, hence establishing a very intricate co-dependency between $g_{\mathrm{s}}$ and $g_{\mathrm{m}}$ limitations at different time scales that deserves further study. In line with this, Lehmeier et al. ${ }^{147}$ showed that it is possible to genetically modify cell density and the arrangement of the air channels with an overall decreased path tortuosity in the palisade air spaces in a way that facilitates $g_{\mathrm{m}}$ without affecting $g_{\mathrm{s}}$. Similarly, alteration of leaf mesophyll anatomy of Eucalyptus has been attempted by the overexpression of the transcription factor EcHBl, which is involved in multiple genes related to cell wall biosynthesis and cell growth, increasing the number of chloroplasts per unit leaf area and therefore enhancing $\mathrm{CO}_{2}$ diffusion into chloroplasts and photosynthesis ${ }^{148}$. These results offer new possibilities in improving photosynthesis by reducing $\mathrm{CO}_{2}$ diffusion limitations. Advances in the understanding of cell wall composition determinants of $g_{\mathrm{m}}$ may open complementary doors in the near future.

While significant and important in some cases, the abovedescribed manipulations aimed to improve maximum photosynthesis rates, i.e. light-saturated photosynthesis in the absence of abiotic and biotic stresses. However, photosynthesis in nature occurs in largely variable conditions, e.g. in fluctuating light. For instance, De Souza et al..$^{43}$ showed in cassava that, while under steady-state high-light conditions, $g_{\mathrm{m}}$ and biochemical limitations accounted for up to $84 \%$ of the total photosynthetic limitation and, under non-steady state conditions during shade to sun transition, $g_{s}$ became the most dominant limitation. Thus, in recent years, research has focused on improving photosynthesis and efficiency under non-steady-state conditions by decreasing the excess absorption of light ${ }^{15,149}$ or increasing the relaxing velocity of photoprotection ${ }^{150-152}$. More surprisingly, overexpressing $\mathrm{PsbS}$ in transgenic tobacco resulted in enhanced WUE by reducing $g_{\mathrm{s}}$, not increasing photosynthesis, again pointing to potential mesophyll signals in stomata regulation ${ }^{153}$. Recently, Papanatsiou et al ${ }^{154}$ used an optogenetic approach to improve photosynthesis, WUE, and growth in Arabidopsis. They expressed a synthetic light-gated $\mathrm{K}^{+}$channel in stomatal guard cells (BLINK1), which improved the speed of stomata kinetics in response to varying light. Increased velocity of stomata opening from a dark-to-light transition and closing from a light-to-dark transition resulted in increased plant growth and WUE by approximately $30 \%{ }^{154}$.

\section{Conclusion}

Light sensing, photoprotection, $\mathrm{CO}_{2}$ diffusion, and its fixation involve numerous and complex processes that are far from fully understood. In the last few years, new insights have been obtained into how interaction and conformation of lightharvesting complexes and photosystems affect photoprotection and heat dissipation. Advances have been made also in the understanding of the variability in rubisco kinetics and photosynthetic limitations at steady state along the plant's phylogeny, of the genetics and mechanistic aspects of carbon-concentrating mechanisms, and of the major anatomical determinants of $g_{\mathrm{m}}$ and the metabolic determinants of stomatal conductance and kinetics. Important links between mesophyll 
and stomatal cells have been revealed, although the signaling between mesophyll cells and guard cells that regulates $g_{s}$ requires further research, as does understanding the chemical and biochemical determinants of $g_{\mathrm{m}}$.

Nevertheless, owing to the new knowledge acquired, engineering efforts for improving photosynthesis and photosynthetic WUE have been attempted, some of them with significant success, which open up the opportunity for photosynthesis-mediated improvement of crop productivity in the forthcoming years. To achieve this goal, a close collaboration among plant physiologists, molecular biologists, geneticists, and agronomists might be essential for generating multiple new photosynthetic genotypes and evaluating them under realistic conditions, both under steady- and non-steady-state conditions, from a photosynthetic limitations perspective to a yield and WUE perspective ${ }^{122}$. Technical advances in analytical tools, like the recently implemented rapid $\mathrm{CO}_{2}$ response curves of gas exchange ${ }^{155-159}$, would be crucial to allow in-depth phenotyping of photosynthesis in record times.
1. Hill R: Oxygen evolved by isolated chloroplasts. Nature. 1937; 139: 881-2. Publisher Full Text

2. Hill R: Oxygen produced by isolated chloroplasts. Proc R Soc Lond B. 1939; 127(847): 192-210

Publisher Full Text

3. Calvin $\mathrm{M}$, Bassham JA, Benson $\mathrm{AA}$, et al:: Carbon dioxide assimilation in plants In: V Symposia of the Society for Experimental Biology: 284-305 January 1951; Cambridge.

4. Khorobrykh S, Havurinne V, Mattila $\mathrm{H}$, et al.: Oxygen and ROS in photosynthesis. Plants (Basel). 2020; 9(1): 91.

PubMed Abstract | Publisher Full Text | Free Full Text

5. Murchie EH, Ruban AV: Dynamic non-photochemical quenching in plants: From molecular mechanism to productivity. Plant J. 2020; 101(4): 885-96. PubMed Abstract | Publisher Full Text

6. Sunil B, Saini D, Bapatla RB, et al.: Photorespiration is complemented by cyclic electron flow and the alternative oxidase pathway to optimize photosynthesis and protect against abiotic stress. Photosyn Res. 2019; 139(1-3): 67-79. PubMed Abstract | Publisher Full Text

7. Krieger-Liszkay A, Krupinska K, Shimakawa G: The impact of photosynthesis on initiation of leaf senescence. Physiol Plant. 2019; 166(1): 148-64. PubMed Abstract | Publisher Full Text

8. Miller MAE, O'Cualain R, Selley J, et al:: Dynamic acclimation to high light in Arabidopsis thaliana involves widespread reengineering of the leaf proteome. Front Plant Sci. 2017; 8: 1239.

PubMed Abstract | Publisher Full Text | Free Full Text

9. Albanese $\mathrm{P}$, Manfredi M, Re A, et al.: Thylakoid proteome modulation in pea plants grown at different irradiances: Quantitative proteomic profiling in a non-model organism aided by transcriptomic data integration. Plant $J .2018$ 96(4): 786-800.

PubMed Abstract | Publisher Full Text | Faculty Opinions Recommendation

10. Sacharz J, Giovagnetti V, Ungerer P, et al.: The xanthophyll cycle affects reversible interactions between PsbS and light-harvesting complex II to control non-photochemical quenching. Nat Plants. 2017; 3: 16225. PubMed Abstract | Publisher Full Text

11. Janik E, Bednarska J, Sowinski K, et al:: Light-induced formation of dimeric LHCll. Photosyn Res. 2017; 132(3): 265-76.

PubMed Abstract | Publisher Full Text | Free Full Text

12. Albanese $\mathrm{P}$, Manfredi $\mathrm{M}$, Marengo $\mathrm{E}$, et al:: Structural and functional differentiation of the light-harvesting protein Lhcb4 during land plant diversification. Physiol Plant. 2019; 166(1): 336-50.

PubMed Abstract | Publisher Full Text | Faculty Opinions Recommendation

13. Taylor SH, Long SP: Slow induction of photosynthesis on shade to sun transitions in wheat may cost at least $21 \%$ of productivity. Philos Trans $R$ Soc Lond B Biol Sci. 2017; 372(1730): 20160543. PubMed Abstract | Publisher Full Text | Free Full Text

14. Walker BJ, Drewry DT, Slattery RA, et al.: Chlorophyll can be reduced in crop canopies with little penalty to photosynthesis. Plant Physiol. 2018; 176(2): 1215-32.

PubMed Abstract | Publisher Full Text | Free Full Text

Faculty Opinions Recommendation

15. Song $\mathrm{Q}$, Wang $\mathrm{Y}, \mathrm{Qu} \mathrm{M}$, et al.: The impact of modifying photosystem antenna size on canopy photosynthetic efficiency-development of a new canopy photosynthesis model scaling from metabolism to canopy level processes. Plant Cell Environ. 2017; 40(12): 2946-57. PubMed Abstract | Publisher Full Text | Free Full Text
16. Morales F, Ancín M, Fakhet D, et al.: Photosynthetic metabolism under stressful growth conditions as a bases for crop breeding and yield improvement. Plants (Basel). 2020; 9(1): 88.

PubMed Abstract | Publisher Full Text | Free Full Text

17. Wang Y, Li J: Molecular basis of plant architecture. Annu Rev Plant Biol. 2008; 59: 253-79.

PubMed Abstract | Publisher Full Text

18. Ouzounis $\mathrm{T}$, Rosenqvist $\mathrm{E}$, Ottosen $\mathrm{CO}$ : Spectral effects of artificial light on plant physiology and secondary metabolism: a review. Hortsci. 2015; 50(8): 1128-35. Publisher Full Text

19. Hamdani S, Khan N, Perveen S, et al:: Changes in the photosynthesis properties and photoprotection capacity in rice (Oryza sativa) grown under red, blue, or white light. Photosyn Res. 2019; 139(1-3): 107-21. PubMed Abstract | Publisher Full Text

20. Górecka M, Lewandowska M, Dąbrowska-Bronk J, et al.: Photosystem II $22 \mathrm{kDa}$ protein level - a prerequisite for excess light-inducible memory, crosstolerance to UV-C and regulation of electrical signalling. Plant Cell Environ. 2019; 43(3): 649-61.

2019; 43(3): 649-61.

21. Berry ZC, Goldsmith GR: Diffuse light and wetting differentially affect tropical tree leaf photosynthesis. New Phytol. 2020; 225(1): 143-53. PubMed Abstract | Publisher Full Text | Faculty Opinions Recommendation

22. Hermida-Carrera C, Kapralov MV, Galmés J: Rubisco catalytic properties and temperature response in crops. Plant Physiol. 2016; 171(4): 143-61. PubMed Abstract | Publisher Full Text | Free Full Text

23. Orr DJ, Alcântara A, Kapralov MV, et al: Surveying Rubisco diversity and temperature response to improve crop photosynthetic efficiency. Plant Physiol. 2016; 172(2): 707-17.

PubMed Abstract | Publisher Full Text | Free Full Text

24. Iñiguez C, Capó-Bauçà S, Niinemets Ü, et al.: Evolutionary trends in RuBisCO kinetics and their co-evolution with $\mathrm{CO}_{2}$ concentrating mechanisms. Plant J. 2020; 101(4): 897-918.

PubMed Abstract | Publisher Full Text | Faculty Opinions Recommendation

25. Flamholz Al, Prywes N, Moran U, et al.: Revisiting Trade-offs between Rubisco Kinetic Parameters. Biochemistry. 2019; 58(31): 3365-76. PubMed Abstract | Publisher Full Text | Free Full Text

26. Hermida-Carrera C, Fares MA, Font-Carrascosa M, et al.: Exploring molecular evolution of Rubisco in $\mathrm{C}_{3}$ and CAM Orchidaceae and Bromeliaceae. BMC EVOI Biol. 2020; 20(1): 11.

PubMed Abstract | Publisher Full Text | Free Full Text |

Faculty Opinions Recommendation

27. Ermakova M, Danila FR, Furbank RT, et al:: On the road to $\mathrm{C}_{4}$ rice: Advances and perspectives. Plant J. 2020; 101(4): 940-50. PubMed Abstract | Publisher Full Text | Free Full Text

28. Vicente-Serrano SM, Lopez-Moreno Jl, Beguería S, et al.: Evidence of increasing drought severity caused by temperature rise in southern Europe. Environ Res Lett. 2014; 9(4): 44001. Publisher Full Text

29. Carnicer J, Domingo-Marimon C, Ninyerola M, et al:: Regime shifts of Mediterranean forest carbon uptake and reduced resilience driven by multidecadal ocean surface temperatures. Glob Chang Biol. 2019; 25(8): 2825-40.

PubMed Abstract | Publisher Full Text | Faculty Opinions Recommendation

30. Yan W, Zhong $Y$, Shangguan Z: A meta-analysis of leaf gas exchange and water 
status responses to drought. Sci Rep. 2016; 6: 20917. PubMed Abstract | Publisher Full Text | Free Full Text

31. Borland AM, Hartwell J, Weston DJ, et al:: Engineering crassulacean acid metabolism to improve water-use efficiency. Trends Plant Sci. 2014; 19(5): 327-38.

PubMed Abstract | Publisher Full Text | Free Full Text

32. Borland AM, Wullschleger SD, Weston DJ, et al.: Climate-resilient agroforestry: Physiological responses to climate change and engineering of crassulacean acid metabolism (CAM) as a mitigation strategy. Plant Cell Environ. 2015; 38(9): 1833-49.

PubMed Abstract | Publisher Full Text

33. Jenkins CLD, Furbank RT, Hatch MD: Mechanism of c(4) photosynthesis: a model describing the inorganic carbon pool in bundle sheath cells. Plant Physiol. 1989; 91(4): 1372-81.

PubMled Abstract | Publisher Full Text | Free Full Text

34. Badger MR, Kaplan A, Berry JA: Internal Inorganic Carbon Pool of Chlamydomonas reinhardtii: evidence for a carbon dioxide-concentrating mechanism. Plant Physiol. 1980; 66(3): 407-13.

PubMed Abstract | Publisher Full Text | Free Full Text

35. Badger MR, Andrews TJ: Co-evolution of Rubisco and $\mathrm{CO} 2$ concentrating mechanisms. In Progress in Photosynthesis Research. Edited by Biggins J. Dordrecht: Springer; 1987; 601-609. Publisher Full Text

36. Rae BD, Long BM, Förster B, et al:: Progress and challenges of engineering a biophysical $\mathrm{CO}_{2}$-concentrating mechanism into higher plants. $J$ Exp Bot 2017; 68(14): 3717-37.

PubMed Abstract | Publisher Full Text | Faculty Opinions Recommendation

37. Veromann-Jürgenson LL, Tosens $\mathrm{T}$, Laanisto $\mathrm{L}$, et al.: Extremely thick cell walls and low mesophyll conductance: Welcome to the world of ancient living! J Exp Bot. 2017; 68(7): 1639-53.

PubMed Abstract | Publisher Full Text | Free Full Text

38. Peguero-Pina JJ, Sisó S, Flexas J, et al:: Cell-level anatomical characteristics explain high mesophyll conductance and photosynthetic capacity in sclerophyllous Mediterranean oaks. New Phytol. 2017; 214(2): 585-96. PubMed Abstract | Publisher Full Text

39. Carriquí M, Roig-Oliver M, Brodribb TJ, et al:: Anatomical constraints to nonstomatal diffusion conductance and photosynthesis in lycophytes and bryophytes. New Phytol. 2019; 222(3): 1256-70. PubMed Abstract | Publisher Full Text

40. Lu Z, Xie K, Pan Y, et al:: Potassium mediates coordination of leaf photosynthesis and hydraulic conductance by modifications of leaf anatomy. Plant Cell Environ. 2019; 42(7): 2231-44.

PubMed Abstract | Publisher Full Text | Faculty Opinions Recommendation

41. Veromann-Jürgenson LL, Brodribb TJ, Niinemets Ü: Pivotal role of mesophyll conductance in shaping photosynthetic performance across 67 structurally diverse gymnosperm species. Int J Plant Sci. 2020; 181(1): 116-28. Publisher Full Text

42. $\mathrm{Xu} Y$, Feng $Z$, Shang B, et al.: Mesophyll conductance limitation of photosynthesis in poplar under elevated ozone. Sci Total Environ. 2019; 657 136-45.

PubMed Abstract | Publisher Full Text

43. de Souza AP, Wang Y, Orr DJ, et al.: Photosynthesis across African cassava germplasm is limited by Rubisco and mesophyll conductance at steady state, but by stomatal conductance in fluctuating light. New Phytol. 2020; 225(6) 2498-512.

PubMed Abstract | Publisher Full Text | Free Full Text

44. Xie K, Lu Z, Pan Y, et al:: Leaf photosynthesis is mediated by the coordination of nitrogen and potassium: The importance of anatomical-determined mesophyll conductance to $\mathrm{CO}_{2}$ and carboxylation capacity. Plant Sci. 2020; 290: 110267 .

PubMed Abstract | Publisher Full Text

45. Bahar NHA, Hayes L, Scafaro AP, et al.: Mesophyll conductance does not contribute to greater photosynthetic rate per unit nitrogen in temperate compared with tropical evergreen wet-forest tree leaves. New Phytol. 2018; 218(2): 492-505.

PubMed Abstract | Publisher Full Text

46. Gago J, Carriquí M, Nadal M, et al:: Photosynthesis optimized across land plant phylogeny. Trends Plant Sci. 2019; 24(10): 947-58.

PubMed Abstract | Publisher Full Text

47. Flexas J, Barbour MM, Brendel O, et al:: Mesophyll diffusion conductance to $\mathrm{CO}_{2}$ : An unappreciated central player in photosynthesis. Plant Sci. 2012; 193-194: 70-84.

PubMed Abstract | Publisher Full Text

48. Flexas J, Díaz-Espejo A, Conesa MA, et al.: Mesophyll conductance to $\mathrm{CO}_{2}$ and Rubisco as targets for improving intrinsic water use efficiency in $\mathrm{C} 3$ plants. Plant Cell Environ. 2016; 39(5): 965-82. PubMed Abstract | Publisher Full Text

49. Nadal M, Flexas J: Mesophyll Conductance to $\mathrm{CO}_{2}$ Diffusion: Effects of Drought and Opportunities for Improvement. In Water scarcity and sustainable agriculture in semiarid environment. Edited by Iván Francisco García Tejero and Víctor Hugo Durá n Zuazo: Academic Press; 2018; 403-438.

Publisher Full Text
50. Tholen D, Éthier G, Genty B: Mesophyll conductance with a twist. Plant Cell Environ. 2014; 37(11): 2456-8.

PubMed Abstract | Publisher Full Text

51. Ubierna N, Cernusak LA, Holloway-Phillips M, et al.: Critical review: Incorporating the arrangement of mitochondria and chloroplasts into models of photosynthesis and carbon isotope discrimination. Photosyn Res. 2019; 141(1) 5-31. PubMed Abstract | Publisher Full Text

52. Busch FA, Holloway-Phillips M, Stuart-Williams $\mathrm{H}$, et al:: Revisiting carbon isotope discrimination in $\mathrm{C} 3$ plants shows respiration rules when photosynthesis is low. Nat Plants. 2020; 6(3): 245-58.

PubMed Abstract | Publisher Full Text

53. Tomás M, Flexas J, Copolovici L, et al.: Importance of leaf anatomy in determining mesophyll diffusion conductance to $\mathrm{CO}_{2}$ across species: Quantitative limitations and scaling up by models. J Exp Bot. 2013; 64(8) 2269-81.

PubMed Abstract | Publisher Full Text | Free Full Text

54. Tosens T, Nishida K, Gago J, et al.: The photosynthetic capacity in $\mathbf{3 5}$ ferns and fern allies: Mesophyll $\mathrm{CO}_{2}$ diffusion as a key trait. New Phytol. 2016; 209(4): 1576-90.

PubMed Abstract | Publisher Full Text

55. Yamori W, Noguchi K, Hanba YT, et al:: Effects of internal conductance on the temperature dependence of the photosynthetic rate in spinach leaves from contrasting growth temperatures. Plant Cell Physiol. 2006; 47(8): 1069-80. PubMed Abstract | Publisher Full Text

56. Bernacchi CJ, Portis AR, Nakano H, et al:: Temperature Response of Mesophyll Conductance. Implications for the Determination of Rubisco Enzyme Kinetics and for Limitations to Photosynthesis in Vivo. Plant Physiol. 2002; 130(4): 1992-8.

PubMed Abstract | Publisher Full Text | Free Full Text

57. Carriquí $\mathrm{M}$, Douthe $\mathrm{C}$, Molins $\mathrm{A}$, et al.: Leaf anatomy does not explain apparent short-term responses of mesophyll conductance to light and $\mathrm{CO}_{2}$ in tobacco. Physiol Plant. 2019; 165(3): 604-18.

PubMed Abstract | Publisher Full Text

58. Evans JR, von Caemmerer S: Temperature response of carbon isotope discrimination and mesophyll conductance in tobacco. Plant Cell Environ. 2013; 36(4): 745-56.

PubMed Abstract | Publisher Full Text

59. Walker B, Ariza LS, Kaines S, et al.: Temperature response of in vivo Rubisco kinetics and mesophyll conductance in Arabidopsis thaliana: Comparisons to Nicotiana tabacum. Plant Cell Environ. 2013; 36(12): 2108-19.

PubMed Abstract | Publisher Full Text

60. von Caemmerer S, Evans JR: Temperature responses of mesophyll conductance differ greatly between species. Plant Cell Environ. 2015; 38(4): 629-37.

PubMed Abstract | Publisher Full Text

61. Terashima I, Hanba YT, Tholen D, et al.: Leaf functional anatomy in relation to photosynthesis. Plant Physiol. 2011; 155(1): 108-16.

PubMed Abstract | Publisher Full Text | Free Full Tex

62. Gorton HL, Herbert SK, Vogelmann TC: Photoacoustic analysis indicates that chloroplast movement does not alter liquid-phase $\mathrm{CO}_{2}$ diffusion in leaves of Alocasia brisbanensis. Plant Physiol. 2003; 132(3): 1529-39.

PubMed Abstract | Publisher Full Text | Free Full Text

63. Loreto $\mathrm{F}, \mathrm{Tsonev} \mathrm{T}$, Centritto $\mathrm{M}$ : The impact of blue light on leaf mesophyll conductance. J Exp Bot. 2009; 60(8): 2283-90.

PubMed Abstract | Publisher Full Text

64. Tholen D, Boom C, Noguchi KO et al: The chloroplast avoidance response decreases internal conductance to $\mathrm{CO}_{2}$ diffusion in Arabidopsis thalian leaves. Plant Cell Environ. 2008; 31(11): 1688-700. PubMed Abstract | Publisher Full Text

65. Momayyezi M, McKown AD, Bell SCS, et al.: Emerging roles for carbonic anhydrase in mesophyll conductance and photosynthesis. Plant $J$.2020; 101(4): 831-44.

PubMed Abstract | Publisher Full Text

66. Momayyezi M, Guy RD: Substantial role for carbonic anhydrase in latitudinal variation in mesophyll conductance of Populus trichocarpa Torr. \& Gray. Plant Cell Environ. 2017; 40(1): 138-49. PubMed Abstract | Publisher Full Text

67. Momayyezi M, Guy RD: Blue light differentially represses mesophyll conductance in high vs low latitude genotypes of Populus trichocarpa Torr. \& Gray. J Plant Physiol. 2017; 213: 122-8. PubMed Abstract | Publisher Full Text

68. Momayyezi M, Guy RD: Concomitant effects of mercuric chloride on mesophyll conductance and carbonic anhydrase activity in Populus trichocarpa Torr. \& Gray. Trees. 2018; 32: 301-9. Publisher Full Text

69. Han J, Lei Z, Zhang Y, et al:: Drought-introduced variability of mesophyll conductance in Gossypium and its relationship with leaf anatomy. Physiol Plant. 2019; 166(3): 873-87.

PubMed Abstract | Publisher Full Text | Faculty Opinions Recommendation

70. Kolbe AR, Cousins AB: Mesophyll conductance in Zea mays responds 
transiently to $\mathrm{CO}_{2}$ availability: Implications for transpiration efficiency in $\mathrm{C}_{4}$ crops. New Phytol. 2018; 217(4): 1463-74.

PubMed Abstract | Publisher Full Text | Faculty Opinions Recommendation

71. Uehlein N, Kai L, Kaldenhoff R: Plant aquaporins and $\mathrm{CO}_{2}$. In: Plant aquaporins. From transport to signaling. Edited by François Chaumont and Stephen D. Tyerman. New York: Springer. 2017; 255-265.

Publisher Full Text

72. Terashima I, Ono K: Effects of $\mathrm{HgCl}_{2}$ on $\mathrm{CO}_{2}$ dependence of lea photosynthesis: evidence indicating involvement of aquaporins in $\mathrm{CO}_{2}$ diffusion across the plasma membrane Plant Cell Physiol. 2002; 43(1): 70-8. PubMed Abstract | Publisher Full Text

73. Uehlein N, Lovisolo C, Siefritz F, et al.: The tobacco aquaporin NtAQP1 is a membrane $\mathrm{CO}_{2}$ pore with physiological functions. Nature. 2003; 425(6959): 734-7.

PubMed Abstract | Publisher Full Text | Faculty Opinions Recommendation

74. Hanba YT, Shibasaka M, Hayashi Y, et al:: Overexpression of the barley aquaporin HvPIP2;1 increases internal $\mathrm{CO}_{2}$ conductance and $\mathrm{CO}_{2}$ assimilation in the leaves of transgenic rice plants. Plant Cell Physiol. 2004; 45(5): 521-9. PubMed Abstract | Publisher Full Text

75. Otto B, Uehlein N, Sdorra S, et al.: Aquaporin tetramer composition modifies the function of tobacco aquaporins. J Biol Chem. 2010; 285(41): 31253-60. PubMed Abstract | Publisher Full Text | Free Full Text

76. Kawase M, Hanba YT, Katsuhara M: The photosynthetic response of tobacco plants overexpressing ice plant aquaporin McMIPB to a soil water deficit and high vapor pressure deficit. J Plant Res. 2013; 126(4): 517-27. PubMed Abstract | Publisher Full Text | Free Full Text

77. Flexas J, Ribas-Carbó M, Hanson DT, et al.: Tobacco aquaporin NtAQP1 is involved in mesophyll conductance to $\mathrm{CO}_{2}$ in vivo. Plant J. 2006; 48(3): 427-39. PubMed Abstract | Publisher Full Text

78. Uehlein N, Otto B, Hanson DT, et al:: Function of Nicotiana tabacum aquaporins as chloroplast gas pores challenges the concept of membrane $\mathrm{CO}_{2}$ permeability. Plant Cell. 2008; 20(3): 648-57.

PubMed Abstract | Publisher Full Text | Free Full Text |

Faculty Opinions Recommendation

79. Heckwolf M, Pater D, Hanson DT, et al:: The Arabidopsis thaliana aquaporin AtPIP1;2 is a physiologically relevant $\mathrm{CO}_{2}$ transport facilitator. Plant J. 2011; 67(5): 795-804.

PubMed Abstract | Publisher Full Text | Faculty Opinions Recommendation

80. Sade N, Shatil-Cohen A, Attia Z, et al:: The role of plasma membrane aquaporins in regulating the bundle sheath-mesophyll continuum and leaf hydraulics. Plant Physiol. 2014; 166(3): 1609-20.

PubMed Abstract | Publisher Full Text | Free Full Text

81. Tolleter $\mathrm{D}$, Chochois V, Poiré $\mathrm{R}$, et al:: Measuring $\mathrm{CO}_{2}$ and $\mathrm{HCO}_{3}$ - permeabilities of isolated chloroplasts using a MIMS-18O approach. J Exp Bot. 2017; 68(14): 3915-24.

PubMed Abstract | Publisher Full Text | Free Full Text

82. Kromdijk J, Głowacka K, Long SP: Photosynthetic efficiency and mesophyll conductance are unaffected in Arabidopsis thaliana aquaporin knock-out lines. J Exp Bot. 2020; 17(1): 318-329.

PubMed Abstract | Publisher Full Text | Faculty Opinions Recommendation

83. Théroux-Rancourt G, Earles JM, Gilbert ME, et al:: The bias of a two-dimensional view: comparing two-dimensional and three-dimensional mesophyll surface area estimates using noninvasive imaging. New Phytol. 2017; 215(4): 1609-22. PubMed Abstract | Publisher Full Text

84. Harwood R, Goodman E, Gudmundsdottir M, et al:: Cell and chloroplast anatomical features are poorly estimated from 2D cross-sections. New Phytol. 2020; 225(6): 2567-78.

PubMed Abstract | Publisher Full Text

85. Niinemets Ü, Reichstein M: Controls on the emission of plant volatiles through stomata: Differential sensitivity of emission rates to stomatal closure explained. J Geophys Res. 2003; 108(D7): 267. Publisher Full Text

86. Tosens $\mathrm{T}$, Niinemets $\mathrm{U}$, Westoby M, et al.: Anatomical basis of variation in mesophyll resistance in eastern Australian sclerophylls: news of a long and winding path. J Exp Bot. 2012; 63(14): 5105-19. PubMed Abstract | Publisher Full Text | Free Full Text

87. Earles JM, Buckley TN, Brodersen CR, et al.: Embracing 3D Complexity in Leaf Carbon-Water Exchange. Trends Plant Sci. 2019; 24(1): 15-24. PubMed Abstract | Publisher Full Text | Faculty Opinions Recommendation

88. Niinemets U, Díaz-Espejo A, Flexas J, et al.: Role of mesophyll diffusion conductance in constraining potential photosynthetic productivity in the field. J Exp Bot. 2009; 60(8): 2249-70.

PubMed Abstract | Publisher Full Text

89. Gago J, de Menezes Daloso D, Figueroa CM, et al.: Relationships of Leaf Net Photosynthesis, Stomatal Conductance, and Mesophyll Conductance to Primary Metabolism: A Multispecies Meta-Analysis Approach. Plant Physiol. 2016; 171(1): 265-79.

PubMed Abstract | Publisher Full Text | Free Full Text

90. Ellsworth PV, Ellsworth PZ, Koteyeva NK, et al:: Cell wall properties in Oryza sativa influence mesophyll $\mathrm{CO}_{2}$ conductance. New Phytol. 2018; 219(1): 66-76. PubMed Abstract | Publisher Full Text | Faculty Opinions Recommendation
91. Clemente-Moreno MJ, Gago J, Díaz-Vivancos P, Bernal A, et al.: The apoplastic antioxidant system and altered cell wall dynamics influence mesophyll conductance and the rate of photosynthesis. Plant J. 2019; 99(6): 1031-46. PubMed Abstract | Publisher Full Text

92. Roig-Oliver M, Nadal M, Clemente-Moreno MJ, et al:: Cell wall components regulate photosynthesis and leaf water relations of Vitis vinifera cv. Grenache acclimated to contrasting environmental conditions. J Plant Physiol. 2020; 244: 153084.

PubMed Abstract | Publisher Full Text

93. Harrison EL, Arce Cubas L, Gray JE, et al:: The influence of stomatal morphology and distribution on photosynthetic gas exchange. Plant J. 2020; 101(4): 768-79.

PubMed Abstract | Publisher Full Text | Free Full Text

94. Qi X, Torii KU: Hormonal and environmental signals guiding stomatal development. BMC Biol. 2018; 16(1): 21

PubMed Abstract | Publisher Full Text | Free Full Text

95. Engineer $\mathrm{CB}$, Hashimoto-Sugimoto $\mathrm{M}$, Negi J, et al.: $\mathrm{CO}_{2}$ sensing and $\mathrm{CO}_{2}$ regulation of stomatal conductance: advances and open questions. Trends Plant Sci. 2016; 21(1): 16-30.

PubMed Abstract | Publisher Full Text | Free Full Text

96. Lawson $\mathrm{T}$, Vialet-Chabrand S: Speedy stomata, photosynthesis and plant water use efficiency. New Phytol. 2019; 221(1): 93-8.

PubMed Abstract | Publisher Full Text

97. Brodribb TJ, McAdam SAM: Passive origins of stomatal control in vascular plants. Science. 2011; 331(6017): 582-5 PubMed Abstract | Publisher Full Text

98. McAdam SAM, Brodribb TJ: Fern and lycophyte guard cells do not respond to endogenous abscisic acid. Plant Cell. 2012; 24(4): 1510-21. PubMed Abstract | Publisher Full Text | Free Full Text | Faculty Opinions Recommendation

99. D Deans RM, Brodribb TJ, Busch FA, et al.: Plant water-use strategy mediates stomatal effects on the light induction of photosynthesis. New Phytol. 2019; 222(1): 382-95

PubMed Abstract | Publisher Full Text | Faculty Opinions Recommendation

100. Lima VF, Anjos LD, Medeiros DB, et al.: The sucrose-to-malate ratio correlates with the faster $\mathrm{CO}_{2}$ and light stomatal responses of angiosperms compared to ferns. New Phytol. 2019; 223(4): 1873-87. PubMed Abstract | Publisher Full Text | Faculty Opinions Recommendation

101. Brodribb TJ, McAdam SAM: Evolution of the stomatal regulation of plant water content. Plant Physiol. 2017; 174(2): 639-49. PubMed Abstract | Publisher Full Text | Free Full Text | Faculty Opinions Recommendation

102. Robaina-Estévez S, Daloso DM, Zhang Y, et al:: Resolving the central metabolism of Arabidopsis guard cells. Sci Rep. 2017; 7(1): 8307 PubMed Abstract | Publisher Full Text | Free Full Text

103. Lima VF, Medeiros DB, Dos Anjos L, et al: Toward multifaceted roles of sucrose in the regulation of stomatal movement. Plant Signal Behav. 2018; 13(8): e1494468.

PubMed Abstract | Publisher Full Text | Free Full Text

104. Medeiros DB, Perez Souza L, Antunes WC, et al:: Sucrose breakdown within guard cells provides substrates for glycolysis and glutamine biosynthesis during light-induced stomatal opening. Plant J. 2018; 94(4): 583-94. PubMed Abstract | Publisher Full Text

105. W Wang H, Yan S, Xin H, et al:: A subsidiary cell-localized glucose transporter promotes stomatal conductance and photosynthesis. Plant Cell. 2019; 31(6): 1328-43.

PubMed Abstract | Publisher Full Text | Free Full Text |

Faculty Opinions Recommendation

106. Fujita T, Noguchi K, Ozaki H, et al:: Confirmation of mesophyll signals controlling stomatal responses by a newly devised transplanting method. Functional Plant Biol. 2019; 46(5): 467.

PubMed Abstract | Publisher Full Text | Faculty Opinions Recommendation

107. CYoshida T, Anjos LD, Medeiros DB, et al.: Insights into ABA-mediated regulation of guard cell primary metabolism revealed by systems biology approaches. Prog Biophys Mol Biol. 2019; 146: 37-49. PubMed Abstract | Publisher Full Text | Faculty Opinions Recommendation

108. W Wang $\mathrm{X}, \mathrm{Du} \mathrm{T}$, Huang J, et al.: Leaf hydraulic vulnerability triggers the decline in stomatal and mesophyll conductance during drought in rice. $J$ Exp Bot. 2018; 69(16): 4033-45.

PubMed Abstract | Publisher Full Text | Free Full Text | Faculty Opinions Recommendation

109. Flexas J, Carriquí M, Nadal M: Gas exchange and hydraulics during drought in crops: Who drives whom? J Exp Bot. 2018; 69(16): 3791-5 PubMed Abstract | Publisher Full Text | Free Full Text

110. Xiong $D$, Nadal M: Linking water relations and hydraulics with photosynthesis. Plant J. 2020; 101(4): 800-15. PubMed Abstract | Publisher Full Text

111. Hochberg U, Windt CW, Ponomarenko A, et al.: Stomatal closure, basal lea embolism, and shedding protect the hydraulic integrity of grape stems. Plant Physiol. 2017; 174(2): 764-75. PubMed Abstract | Publisher Full Text | Free Full Text 
112. Nadal M, Flexas J, Gulías J, et al.: Possible link between photosynthesis and leaf modulus of elasticity among vascular plants: A new player in leaf traits relationships? Ecol Lett. 2018; 21(9): 1372-9.

PubMed Abstract | Publisher Full Text

113. Sinclair TR, Rufty TW, Lewis RS: Increasing photosynthesis: unlikely solution for world food problem. Trends Plant Sci. 2019; 24(11): 1032-9.

PubMed Abstract | Publisher Full Text

114. Long SP, Marshall-Colon A, Zhu XG: Meeting the global food demand of the future by engineering crop photosynthesis and yield potential. Cell. 2015; 161(1): 56-66. PubMed Abstract | Publisher Full Text | Faculty Opinions Recommendation

115. Cort DR, Merchant SS, Alric J, et al.: Redesigning photosynthesis to sustainably meet global food and bioenergy demand. Proc Natl Acad Sci U S A. 2015; 112(28): 8529-36

PubMed Abstract | Publisher Full Text | Free Full Text

Faculty Opinions Recommendation

116. Flexas $\mathrm{J}$ : Genetic improvement of leaf photosynthesis and intrinsic water use efficiency in C3 plants: Why so much little success? Plant Sci. 2016; 251: 155-61.

PubMed Abstract | Publisher Full Text

117. Simkin AJ, López-Calcagno PE, Raines CA: Feeding the world: Improving photosynthetic efficiency for sustainable crop production. J Exp Bot. 2019; 70(4): 1119-40.

PubMed Abstract | Publisher Full Text | Free Full Text

118. Srivastava A, Villalobos MB, Singh RK: Engineering Photosynthetic Microbes for Sustainable Bioenergy Production. In Contemporary environmental issues and challenges in era of climate change. Edited by Pooja Singh, Rajeev Pratap Singh and Vaibhav Srivastava: Springer; 2020; 183-198. Publisher Full Text

119. Kumar A, Tiwari V, Singh $P$, et al:: Advances and Challenges in Sugarcane Biofuel Development. In Biotechnology for Biofuels: A Sustainable Green Energy Solution. Edited by Nitish Kumar: Springer; 2020; 267-288. Publisher Full Text

120. Bailey-Serres J, Parker JE, Ainsworth EA, et al:: Genetic strategies for improving crop yields. Nature. 2019; 575(7781): 109-18. PubMed Abstract | Publisher Full Text | Free Full Text | Faculty Opinions Recommendation

121. Batista-Silva W, da Fonseca-Pereira $P$, Martins $A O$, et al.: Engineering improved photosynthesis in the era of synthetic biology. Plant Commun. 2020; 1(2): 100032.

Publisher Full Text

122. Flexas J, Gago J: A role for ecophysiology in the 'omics' era. Plant J. 2018; 96(2): 251-9. PubMed Abstract | Publisher Full Text

123. Sharwood RE: Engineering chloroplasts to improve Rubisco catalysis: Prospects for translating improvements into food and fiber crops. New Phytol. 2017; 213(2): 494-510. PubMed Abstract | Publisher Full Text

124. - Bathellier C, Tcherkez G, Lorimer GH, et al.: Rubisco is not really so bad. Plant Cell Environ. 2018; 41(4): 705-16. PubMed Abstract | Publisher Full Text | Faculty Opinions Recommendation

125. W Wada S, Suzuki Y, Takagi D, et al:: Effects of genetic manipulation of the activity of photorespiration on the redox state of photosystem I and its robustness against excess light stress under $\mathrm{CO}_{2}$-limited conditions in rice. Photosyn Res. 2018; 137(3): 431-41.

PubMed Abstract | Publisher Full Text | Faculty Opinions Recommendation

126. Lin MT, Occhialini A, Andralojc PJ, et al:: A faster Rubisco with potential to increase photosynthesis in crops. Nature. 2014; 513(7519): 547-50. PubMed Abstract | Publisher Full Text | Free Full Text

127. Whitney SM, Birch R, Kelso C, et al.: Improving recombinant Rubisco biogenesis, plant photosynthesis and growth by coexpressing its ancillary RAF1 chaperone. Proc Natl Acad Sci U S A. 2015; 112(11): 3564-9. PubMed Abstract | Publisher Full Text | Free Full Text

128. Conlan B, Birch R, Kelso C, et al.: BSD2 is a Rubisco-specific assembly chaperone, forms intermediary hetero-oligomeric complexes, and is nonlimiting to growth in tobacco. Plant Cell Environ. 2019; 42(4): 1287-301. PubMed Abstract | Publisher Full Text

129. Prukayama H, Mizumoto A, Ueguchi C, et al.: Expression level of Rubisco activase negatively correlates with Rubisco content in transgenic rice. Photosyn Res. 2018; 137(3): 465-74. PubMed Abstract | Publisher Full Text | Faculty Opinions Recommendation

130. McGrath JM, Long SP: Can the cyanobacterial carbon-concentrating mechanism increase photosynthesis in crop species? A theoretical analysis. Plant Physiol. 2014; 164(4): 2247-61. PubMed Abstract | Publisher Full Text | Free Full Text

131. Pengelly JJL, Förster B, von Caemmerer S, et al.: Transplastomic integration of a cyanobacterial bicarbonate transporter into tobacco chloroplasts. $J$ Exp Bot. 2014; 65(12): 3071-80.

PubMed Abstract | Publisher Full Text | Free Full Text

132. Atkinson N, Leitão N, Orr DJ, et al.: Rubisco small subunits from the unicellular green alga Chlamydomonas complement Rubisco-deficient mutants of Arabidopsis. New Phytol. 2017; 214(2): 655-67.

PubMed Abstract | Publisher Full Text | Free Full Text

133. Mackinder LCM: The Chlamydomonas $\mathrm{CO}_{2}$-concentrating mechanism and its potential for engineering photosynthesis in plants. New Phytol. 2018; 217(1): 54-61.

PubMed Abstract | Publisher Full Text

134. Clong BM, Hee WY, Sharwood RE, et al:: Carboxysome encapsulation of the $\mathrm{CO}_{2}$-fixing enzyme Rubisco in tobacco chloroplasts. Nat Commun. 2018; 9(1): 3570 .

PubMed Abstract | Publisher Full Text | Free Full Text |

Faculty Opinions Recommendation

135. Nukherjee A, Lau CS, Walker CE, et al:: Thylakoid localized bestrophinlike proteins are essential for the $\mathrm{CO}_{2}$ concentrating mechanism of Chlamydomonas reinhardtii. Proc Natl Acad Sci U S A. 2019; 116(34): 16915-20. PubMed Abstract | Publisher Full Text | Free Full Text | Faculty Opinions Recommendation

136. N Kebeish R, Niessen M, Thiruveedhi K, et al.: Chloroplastic photorespiratory bypass increases photosynthesis and biomass production in Arabidopsis thaliana. Nat Biotechnol. 2007; 25(5): 593-9.

PubMed Abstract | Publisher Full Text | Faculty Opinions Recommendation

137. S South PF, Cavanagh AP, Liu HW, et al.: Synthetic glycolate metabolism pathways stimulate crop growth and productivity in the field. Science. 2019; 363(6422): eaat9077.

PubMed Abstract | Publisher Full Text | Faculty Opinions Recommendation

138. Simkin AJ: Genetic engineering for global food security: photosynthesis and biofortification. Plants (Basel). 2019; 8(12): 586. PubMed Abstract | Publisher Full Text | Free Full Text

139. - López-Calcagno PE, Fisk S, Brown KL, et al:: Overexpressing the H-protein of the glycine cleavage system increases biomass yield in glasshouse and field-grown transgenic tobacco plants. Plant Biotechnol J. 2019; 17(1): 141-51. PubMed Abstract | Publisher Full Text | Free Full Text |

Faculty Opinions Recommendation

140. Driever SM, Simkin AJ, Alotaibi S, et al:: Increased SBPase activity improves photosynthesis and grain yield in wheat grown in greenhouse conditions. Philos Trans R Soc Lond B Biol Sci. 2017; 372(1730): 20160384. PubMed Abstract | Publisher Full Text | Free Full Text

141. Simkin AJ, Lopez-Calcagno PE, Davey PA, et al.: Simultaneous stimulation of sedoheptulose 1,7-bisphosphatase, fructose 1,6-bisphophate aldolase and the photorespiratory glycine decarboxylase-H protein increases $\mathrm{CO}_{2}$ assimilation, vegetative biomass and seed yield in Arabidopsis. Plant Biotechnol J. 2017; 15(7): 805-16. PubMed Abstract | Publisher Full Text | Free Full Text

142. López-Calcagno PE, Brown KL, Simkin AJ, et al:: Stimulating photosynthetic processes increases productivity and water-use efficiency in the field. Nat Plants. 2020; 6(8): 1054-1063.

PubMed Abstract | Publisher Full Text | Faculty Opinions Recommendation

143. Franks PJ, Doheny-Adams WT, Britton-Harper ZJ, et al.: Increasing water-use efficiency directly through genetic manipulation of stomatal density. New Phytol. 2015; 207(1): 188-95.

PubMed Abstract | Publisher Full Text

144. Dunn J, Hunt L, Afsharinafar M, et al.: Reduced stomatal density in bread wheat leads to increased water-use efficiency. J Exp Bot. 2019; 70(18): 4737-48.

PubMed Abstract | Publisher Full Text | Free Full Text | Faculty Opinions Recommendation

145. N Yang Z, Liu J, Tischer SV, et al.: Leveraging abscisic acid receptors for efficient water use in Arabidopsis. Proc Natl Acad Sci U S A. 2016; 113(24): 6791-6.

PubMed Abstract | Publisher Full Text | Free Full Text | Faculty Opinions Recommendation

146. Lundgren MR, Mathers A, Baillie AL, et al:: Mesophyll porosity is modulated by the presence of functional stomata. Nat Commun. 2019; 10(1): 2825. PubMed Abstract | Publisher Full Text | Free Full Text | Faculty Opinions Recommendation

147. Lehmeier C, Pajor R, Lundgren MR, et al:: Cell density and airspace patterning in the leaf can be manipulated to increase leaf photosynthetic capacity. Plant J. 2017; 92(6): 981-94. PubMed Abstract | Publisher Full Text | Free Full Text | Faculty Opinions Recommendation

148. Sasaki K, Ida Y, Kitajima S, et al.: Overexpressing the HD-Zip class II transcription factor EcHB1 from Eucalyptus camaldulensis increased the leaf photosynthesis and drought tolerance of Eucalyptus. Sci Rep. 2019; 9(1): 14121.

PubMed Abstract | Publisher Full Text | Free Full Text

149. Kirst $\mathrm{H}$, Gabilly ST, Niyogi KK, et al:: Photosynthetic antenna engineering to improve crop yields. Planta. 2017; 245(5): 1009-20. PubMed Abstract | Publisher Full Text

150. Kromdijk J, Głowacka K, Leonelli L, et al.: Improving photosynthesis and 
crop productivity by accelerating recovery from photoprotection. Science. 2016; 354(6314): 857-61.

PubMed Abstract | Publisher Full Text | Faculty Opinions Recommendation

151. Hubbart S, Smillie IRA, Heatley M, et al.: Enhanced thylakoid photoprotection can increase yield and canopy radiation use efficiency in rice. Commun Biol. 2018; 1: 22.

PubMed Abstract | Publisher Full Text | Free Full Text

152. W Wang Y, Burgess SJ, de Becker EM, et al.: Photosynthesis in the fleeting shadows: An overlooked opportunity for increasing crop productivity? Plant $\mathrm{J}$. 2020; 101(4): 874-84

PubMed Abstract | Publisher Full Text | Free Full Text Faculty Opinions Recommendation

153. C Głowacka K, Kromdijk J, Kucera K, et al.: Photosystem II Subunit S overexpression increases the efficiency of water use in a field-grown crop. Nat Commun. 2018; 9(1): 868.

PubMed Abstract | Publisher Full Text | Free Full Text |

Faculty Opinions Recommendation

154. Papanatsiou M, Petersen J, Henderson L, et al:: Optogenetic manipulation of stomatal kinetics improves carbon assimilation, water use, and growth.
Science. 2019; 363(6434): 1456-9.

PubMed Abstract | Publisher Full Text | Faculty Opinions Recommendation

155. Stinziano JR, Morgan PB, Lynch DJ, et al:: The rapid A-C response:

Photosynthesis in the phenomic era. Plant Cell Environ. 2017; 40(8): 1256-62. PubMed Abstract | Publisher Full Text

156. Stinziano JR, Adamson RK, Hanson DT: Using multirate rapid $\mathbf{A} / \mathbf{C}_{\mathrm{i}}$ curves as a tool to explore new questions in the photosynthetic physiology of plants. New Phytol. 2019; 222(2): 785-92.

PubMed Abstract | Publisher Full Text

157. Stinziano JR, McDermitt DK, Lynch DJ, et al.: The rapid $\mathbf{A} / \mathbf{C}_{i}$ response: $\mathbf{A}$ guide to best practices. New Phytol. 2019; 221(2): 625-7. PubMed Abstract | Publisher Full Text

158. Taylor SH, Long SP: Phenotyping photosynthesis on the limit - a critical examination of RACiR. New Phytol. 2019; 221(2): 621-4. PubMed Abstract | Publisher Full Text

159. Lawrence EH, Stinziano JR, Hanson DT: Using the rapid A-C response (RACiR) in the Li-Cor 6400 to measure developmental gradients of photosynthetic capacity in poplar. Plant Cell Environ. 2019; 42(2): 740-50. PubMed Abstract | Publisher Full Text | Faculty Opinions Recommendation 